\title{
Teaching Wikipedia Biography: An Experiment in Public History
}

\author{
Marijke Huisman
}

Utrecht University

Envisioning the Internet as a means to breathe new life into the old ideal of collecting all knowledge in one place, Jimmy Wales and Larry Sanger laid the foundations for Wikipedia in 2000 (Lih). Since then, the online encyclopedia has grown into one of the most visited websites on earth, for which innumerable volunteers have written millions of entries (Gray). With over five and a half million pages, the English version of Wikipedia is the largest, but even a small language edition like the Dutch Wikipedia counts almost two million entries. ${ }^{1}$ Many topics are covered by the wide community of Wikipedians, but historical themes and life stories appear to lie very close to their hearts. Based on an analysis of the 1,000 most visited pages of the English-language Wikipedia in 2013, historian David G. Halsted estimated that 20 percent of the entries can be characterized as having "significant historical content." Much of this content is of a biographical nature; according to Pamela Graham, in 2015 some 25 percent of all entries in the English edition of Wikipedia were biographies of living or dead persons.

The taste for biographical-historical content is also visible on the audience's end, as can be seen in Wikipedia's statistics. In the 10 mostvisited pages between December 2007 and September 2017, historical themes like "World War II" appear next to biographical entries on Donald Trump, Barack Obama, Michael Jackson, and Lady Gaga. ${ }^{2}$ Wikipedia's weekly reports show a similar trend. In the first week of August 2017, for instance, 13 of the 25 most visited entries were biographies of noteworthy persons from the past or the present. ${ }^{3}$ The most-visited biographies were on living persons like the Brazilian football player 
Neymar (3), who dominated that week's news because he had received 222 million euros to transfer from FC Barcelona to Paris St. Germain. More historical in content was the biography of Mexican actress Dolores del Rio (1904-1983), who ended up in place 16 because her life was commemorated by a so-called "Google Doodle." Still, non-biographical historical entries were among this week's top 25, too. The Battle of Dunkirk and the Evacuation of Dunkirk in 1940 featured in places 11 and 25 respectively, which can be explained by the then-recent launch of the movie Dunkirk (place 5).

The production and consumption of historical knowledge, both biographical and otherwise, are clearly important parts of the Wikipedia project. Public historian Roy Rosenzweig recognized this back in 2006, urging his fellow historians to pay close attention to the practice of history on Wikipedia. Nonetheless, academic historians often take a sceptical stance towards the online encyclopedia. Few join the community of Wikipedians in writing historical entries, and it is not uncommon for history professors to discourage the use of Wikipedia among their students. In the historical world outside academia, on the other hand, Wikipedia holds a much stronger position. Museums, archives, and other heritage institutions have recognized the power of the online encyclopedia to increase the visibility and use of their collections. Such institutions have also seized the opportunity to employ a so-called "Wikipedian-in-residence," who helps communicate their historical content through Wikipedia by organizing the writing of entries on specific subjects or sources and the selection as well as uploading of digital materials (photos, archival materials) to Wikipedia commons. ${ }^{4}$

Notwithstanding the limited participation of academic historians in Wikipedia, the online encyclopedia has been discovered for the purpose of teaching historical skills. Amanda Seligman, for instance, integrated the use of Wikipedia into a seminar on Historical Method and Research Techniques at the University of Wisconsin-Milwaukee. At Amherst College Martha Saxton used Wikipedia, as a "relatively new tool to teach students some not-so-new methods for evaluating and writing responsible history" (86). It is worth stressing, however, that the historical content on Wikipedia is not just history but public history. Other scholars have already argued that the online encyclopedia is a useful starting point for studies into collective memory and historical interest among the general public (Wolff, Ribbens, and Grever). Here I want to show that Wikipedia can also serve as an entry for teaching public history to undergraduate students. What follows is a reflection on the course "Public History in the Digital Age," which was taught as part of the interdisciplinary Humanities minor "History and Memory in the Digital Age" at Utrecht University in 
the Netherlands. Before sharing my experiences teaching the 2016-2017 edition of this course, I will first sketch its institutional background.

\section{HISTORY AND MEMORY IN THE DIGITAL AGE}

Many students from history and other disciplines in the humanities are interested in uses of the past and wish to work in the worlds of media, museums, heritage institutions, and other places in which public history is practised. These students were the target audience for the interdisciplinary humanities minor "History and Memory in the Digital Age," which Utrecht University offered between 2013-2014 and 2016-2017. Students who chose this minor enrolled in a series of four courses which familiarized them with theoretical notions like "public history" and "collective memory," and invited them to think about the relationships between history, memory, and identity in a world in which information is increasingly created and disseminated through digital media-both by heritage institutions and "common people" like Wikipedians. The students practised working as public historians and cultural mediators through classes that focused on different writing practices and writing for a general audience. ${ }^{5}$

"Public History in the Digital Age" was the first course in the minor program, but was also open to students who did not enroll for the minor. The course was developed by cultural historian Hendrik Henrichs, who specialized in public history and retired from the History department of Utrecht University in 2016. Drawing on his large network within the museum and heritage sector in the Netherlands, Henrichs designed the course in close collaboration with the University Museum in Utrecht and Wikimedia NL, the Dutch branch of the world-wide Wikimedia movement, whose mission is "to bring free educational content to the world." This resulted in a course in which the students studied literature on public history, memory, and digital media, but also went to work as public historians. Their final assignment was therefore not just another academic essay, but to write Wikipedia entries on themes that were of interest to the University Museum.

Over the years students have written Wikipedia entries on a number of themes that the University Museum staff brought forward. In 2013-2014, for example, students researched the history of the Ooglijdersgasthuis [Hospital for Eye Patients] in Utrecht, which was founded by the famous professor F.C. Donders (1818-1889) in 1858. Based on the museum's collection, the students developed entries on various aspects of the scientific and social history of ophthalmology, and uploaded their work during socalled edit-a-thons to Wikipedia. When Henrichs retired, I took over and 


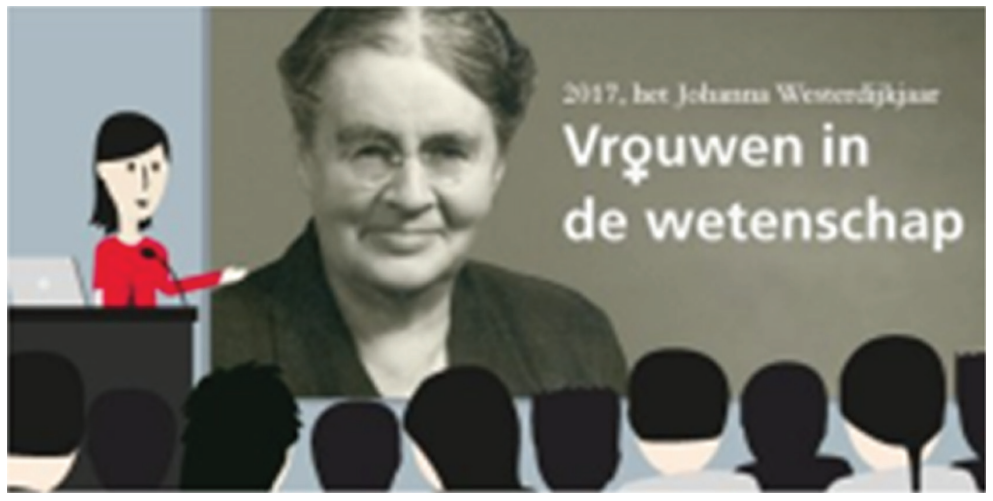

Picture Twitter account Johanna Westerdijkjaar 2017, https://pbs.twimg.com/media/ C2S4NXRWIAQRajE.jpg.

taught the last edition of the course in 2016-2017, for which the University Museum chose the theme of female scholars. This topic anticipated the so-called Westerdijk year (2017), when Dutch academics commemorated biologist Johanna Westerdijk's (1883-1961) becoming professor by special appointment at Utrecht University in 1917, making her the first female professor in the Netherlands (Faasse; Bosch). In this context, students were given the task of writing Wikipedia biographies of twentiethcentury female professors at Utrecht University. Thus, the last edition of the course combined new media, public history, life writing, and gender.

\section{PUBLIC HISTORY AND WIKIPEDIA}

In September 2016, at the start of "Public History in the Digital Age," I asked the ten enrolled students why they had chosen this course. Some answered that they had a special interest in digital media, but most said that they found their studies, be they in History or in other humanities disciplines like Dutch Language and Literature, too academic, and they longed to do something practical, with real meaning and use. These students were attracted by the fact that their final work would not be a paper but something that was asked for by a real-life institution, the University Museum, and distributed to the real world through Wikipedia.

The practical work for the course was but one part of a larger project of thinking about history, its relation to memory, and the role of historians in (digital) public culture. To that end, we started the course reading literature and discussing different traditions in thinking about the 
relation between "history" and "public." One tradition can be described as history for the public, which refers to the social outreach done by professional historians as "public educators" (Tosh, 104). In this tradition, the historian and the rules of the historical discipline are always in the lead. In a second tradition, the focus is much more on the public and the ways in which citizens deal with the past, in whatever way they do so. This 'history by the public' does not follow the usual rules of academic research, and often stretches the very notion of what history is about, what its sources can be, and how it must be undertaken and presented (Samuel). In a third tradition, public history is described in terms of "shared authority" or a "participatory historical culture" (Rosenzweig and Thelen; Kean and Ashton). Both concepts reflect the idea that professional historians do not own the past, but historians and other people, that is, the public, are engaged in a communal project of giving meaning to the past in the present. In this project, which can be understood as a dialogue and/or a fight, the historian is just one of the partners and has lost his claim to have the final word about the past.

When it comes to public history in the digital world, the second and third conceptions are most relevant because there the professional historian is definitely not in the lead (Danniau). The many historical and biographical entries on Wikipedia, for instance, are predominantly written by so-called amateurs; professional historians hardly participate in the making of this major platform of public history. Even so, the students leaned very strongly towards the first conception of public history. Many said they could see an educational task for themselves; they wished to inform the general public about historical backgrounds that help explain the present, or they had a desire to debunk certain myths or misconceptions about the past in the present. In either case, students qualified themselves, or their future selves, as expert-historians and members of the public as their pupils, who were otherwise considered too subjective or superficial to understand the past on their own.

Such a condescending attitude towards the general public always shocks me, but I was even more disturbed by the very naive conception of history that was prevalent among the students. While the majority had a background in history, the students seemed to have forgotten the basic features of their own discipline: that there is not one historical truth, and that the meaning of the past is always open to debate. From teaching undergraduate courses like Introduction to the Historical Discipline and Theory of History, I already knew that many students had trouble accepting the relativism that underlies their discipline, but during this course I wondered to what extent their issues with the interpretative nature of their academic studies might also explain their enthusiasm for Wikipedia 
as a manifestation of history in the real world. The encyclopedia is, after all, built on the principle that entries must be based on "facts" that can be traced back to secondary sources, and must be written from a "neutral point of view" (NPOV). Contrasted with an academic education in which facts, objectivity, and truth are systematically questioned and debated, Wikipedia seemed to offer students something they continued to long for: a positivist safe haven in which the historian still controls "the truth" about the past (Huisman).

\section{NOTABILITY AND GENDER}

But like history, Wikipedia is not exactly free from bias. Other scholars have already pointed out that what is considered "neutral" and "notable" often boils down to what is Western, white, and male (Graham; Reagle). In order to counter these biases, Wikimedia launched a number of initiatives, ranging from a Wikimedia LGBT+Portal to taskforces against systemic biases in terms of religion, politics, geography, and gender. Contesting the so-called "gender gap" are projects in different languages. In the Netherlands, Wikimedia NL created a Gender Gap project which tries to increase both the number of female Wikipedia writers and editors, and the number of entries on "female" topics-ranging from textile art to Second Wave Feminism and biographies of noteworthy women. Our course project of writing biographies of female scholars was, therefore, not only useful for the University Museum, but also for our other partner: Wikimedia NL.

From a teaching perspective, the gender approach served as a handson entry into more abstract questions that are at the heart of (public) history: what is history, what is historical relevance, and who decides? In my experience, however, gender is not such a hot topic among most history and humanities students anymore. I was therefore prepared for the worst when we had our first class and I introduced the assignment of writing Wikipedia biographies on Johanna Westerdijk and other Utrecht-based female scholars from the first half of the twentieth century. Nothing happened, though. When I showed Westerdijk's professorial portrait, some students commented that she "looked like a man," but there was no sign of resistance to the gender theme. So we went to work and read up on Westerdijk, the proportion of female professors in Dutch academia since 1917, gender and the history of science, and the role of biographies in (public) histories of science.

During the first weeks of the course, we also visited the University Museum to meet our "clients" and hear more about the assignment. Next, small teams of students each chose a female scholar from a list provided 
by the museum staff and started to research the womens' lives and works. In the process, the students became very engaged with their biographical subjects. They wanted to set the historical record straight, either by providing these scholars with a new Wikipedia biography or making interventions into a Wikipedia biography that already existed. As a teacher I was very satisfied with the way things were going, and was completely surprised when the students revolted somewhat against the very point of our course: to counter the gender bias in Wikipedia by adding women's biographies.

The students' revolt occurred in the middle of the course, when we had a guest lecture by a researcher who studies the international networks and reception of women writers in the nineteenth century, and uses digital media for both her research and the presentation of her findings. She is also involved in the Gender Gap Project of Wikimedia $\mathrm{NL}$, and I asked her to come over because I found her work to be an interesting combination of digital history, women's history, and public history. During her lecture, however, the students grew ever more silent and it was very evident that something was wrong. The exact problem did not become clear until the end of the guest lecture, when one student expressed the general sentiment with a remark that can be summarized as: "What is the point of all this? Why are you looking for forgotten women writers nobody cares about, and who may have been forgotten for a reason?" Unfortunately, the guest lecturer was not able to respond in a way that the students could appreciate, but I felt that we had to deal with this question seriously, if only because the same critique could be made of our own project of writing biographies of female scientists who had been forgotten. I therefore decided to leave the literature for the next class as it was, and prepared a group talk instead.

\section{"EVERYBODY IS EQUAL"}

In beginning the first class after the unfortunate guest lecture, I simply asked the students what had happened according to them. First, the majority of the group remarked that the topic of the guest lecture did not appeal to them at all: they could not care less about literature and writers, whether male or female. There was no historical relevance here, these students said. I could not agree with them on this, but in hindsight I tend to think that nineteenth-century literature was perhaps not the best topic for drawing this group's attention. When another guest lecturer presented a short quiz asking the students to name "The Most Important Person in Dutch History," quite a few came up with authors, ranging from the humanist Erasmus (1466-1536) to writers of modern Dutch literature 
like Jan Wolkers (1925-2007). Thus, literature was not the key problem here. More important was the second point the students mentioned: that the guest lecturer was an elitist. She had dropped names like Harriet Beecher Stowe and Ina Boudier-Bakker, and was surprised-even a bit shocked-to learn that these names did not ring a bell with the students, who felt stupid and offended at the same time. ${ }^{7}$

Interestingly, we had experienced a confrontation with so-called elitism before. When we first visited the University Museum, the staff mentioned the names of famous Dutch scientists like Herman Boerhaave (1668-1738), after whom a museum for the history of science in Leiden is called. Still, the students did not know his name. However, they did not speak up then but critized the museum staff for its elitism once we were back in our classroom. These setbacks in my efforts to guide students into the "real world" of museums and fellow-historians taught me, once again, to never overestimate students' knowledge base nor their assertiveness. No matter how vocal students may be in class, they often get intimidated when confronted with "real people" (instead of university teachers...) from "real institutions" in the "real world." On my part, I had done my best to inform our guest lecturers and the museum staff about the backgrounds and interests of the students, but apparently this was not enough. Perhaps here lies a different pedagogical task too: to bolster students' confidence in a more general sense. In the short time of this course, however, I decided to address the issue of perceived elitism through a talk about the students' own elitist stance towards the public, and also to point out that teaching is not easy; it requires solid information on one's audience in terms of interests and previous knowledge. In this way, I eventually was able to turn an unfortunate guest lecture into a valuable and practical lesson for future public historians.

However, I wanted to discuss what was at the heart of the matter to me: the question of which lives and histories are notable or forgettable, and who decides, on what grounds. In my mind we had been discussing these questions for weeks already, so I decided to prepare the class discussion from another angle: race. Much more than gender, race and racism are topical themes in public debate in the Netherlands. The Dutch have had intensive discussions about the blackface tradition of Black Pete for years now, and these have morphed into a more general but equally heated debate about the existence of institutional and everyday racism in Dutch society. ${ }^{8}$ Part of this debate is about the question of whether it is time to have a more inclusive version of Dutch history in the public domain, such as in history textbooks and museum exhibitions. ${ }^{9}$ This debate is particularly interesting for (future) public historians. Not only because it is very public, but also because it shows that professional historians are 
definitely not in control of this conversation. Instead, the public debate is dominated by activists, politicians, singers, and other public actors who claim historical authority but do not necessarily abide by the rules of the historical discipline.

In order to get our group talk started, I had prepared a slide (Illustration 1) with four quotations: one from Thomas Jefferson who, in 1787, argued that "Negroes" are not capable of culture, two from the context of the culture and canon wars in the United States, when Christopher Clausen posited that English literature is about colour-blind "quality" (1988) and Henry Louis Gates, Jr. stated that race, gender, and class do matter in designing curriculums for literature and history classes in a multicultural society (1992). Last but not least, I included a quote from my own history teacher who in 1990 refused to teach exam classes because he disagreed with the government's choice of women's history as a theme of the central high school exams. In translation his quotation reads: "Now it's women's history; what else can we expect? Animal history?!"

On a second slide (Illustration 2), I wrote the general questions that I wanted the students to think about: What is literature? Art? Culture? What is science? What is history? Who is worthy of a biography? What is "quality," "memorable," "notable," according to whom, and based on which criteria? Next to these questions I added pictures that I thought would catch the

\section{ILLUSTRATION 1}

- Thomas Jefferson, 1787: 'Comparing them [Negroes] with their faculties of memory they are equal to whites, in reason much inferior, and in imagination they are dull, tasteless and anomalous. Never could I find that a black had uttered a thought above the level of plain narration.'

\section{- C. Clausen, 1988: 'It is not elitist to place major literature at the center} of the English curriculum'

- Dhr. Timmerman, 1990: 'Nu een CSE over vrouwengeschiedenis. Wat krijgen we dan nog meer? Dierengeschiedenis?!'

- Henry Louis Gates, jr., 1992: ‘Ours is a late 20th-c world profoundly fissured by nationality, ethnicity, race, class, and gender. And the only way to transcend those divisions ... is through education that seeks to comprehend the diversity of human culture. (...) There is no tolerance without respect - and no respect without knowledge.' 


\section{ILLUSTRATION 2}

- Wat is Literatuur? Kunst? Cultuur?

- Wat is Wetenschap?

- Wat is Geschiedenis?

- Wie is Biografie-waardig?

$\rightarrow$ wat is 'kwaliteit' - 'memorabel' - 'notable' ....? $\rightarrow$ volgens wie, en welke criteria?

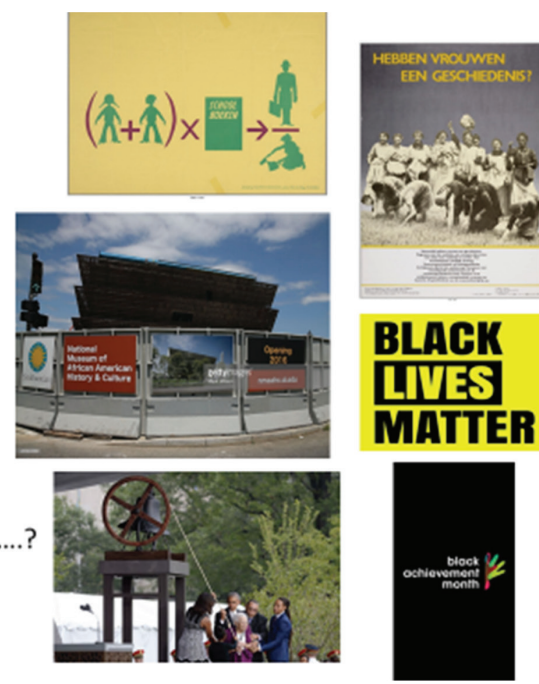

eye and/or provoke the discussion that I intended to have. On the top of the slide I placed two posters from the collection of Atria. Institute on gender equality and women's history: one from the early 1970s, which was distributed by the feminist protest group Man Vrouw Maatschappij [Man Woman Society] to address stereotypical gender patterns in school books (top, left), and another poster by the Women's History Group that, in the mid-1970s, asked "Do women have a history?" (top, right). Underneath I placed two photos of the National Museum of African American History and Culture in Washington, D.C., which Barack Obama opened a few days before our class talk (middle and bottom row, left). Next to these I placed the logos of the Black Lives Matter movement (middle, right) and of Black Achievement Month, which was celebrated for the first time in the Netherlands in October 2016-when we had our class talk-and was organized by the Nationaal Instituut Nederlands Slavernijverleden en Erfenis (NiNSee, National Institute for the History and Legacy of Slavery in the Netherlands).

Reading the quotes on the first slide in class, it did not take long before the group commented that it was discriminatory to suppose that Black people had no historical and cultural relevance because, as some in this all-white group of students said: "everybody is equal." A few students also objected to initiatives that focus on only one category of people. Looking at the logo of the Black Lives Matter movement on the second slide for 
example, students remarked that all lives matter. In response to the picture of the National Museum of African American History and Culture, other students said that such a museum is not necessary, because museums should cover the histories of all people. Upon hearing these statements, I managed to steer the discussion a bit further by asking to what extent these ideals are practiced today, how certain conceptions of what is historical and notable have prevented and still prevent that ideal from becoming reality, and whether it might be necessary sometimes to focus on one group of people to balance the so-called neutral point of view in Wikipedia and other sites of public history and culture.

\section{CONCLUSION}

For me, as teacher, the group talk after the guest lecture on women writers was a great challenge. I had to walk a very fine line between possible accusations of being elitist myself, and a left-leaning, politically correct one at that, and my ambition of having the students think a bit further about the question of which lives are considered notable, hence historical, and who decides on that: "the historian," "the public," or a mix of different parties, and what the answer to this question might mean for the public role of historians. To what extent I have succeeded I am not completely sure. In hindsight, however, I can mention two points by way of conclusion.

My first observation concerns an interesting twist in our classroom discussions on gender, science, the history of science, and what a scientist's biography looks like. In the first weeks we had already compared the structure and contents of biographical entries on female and male scholars in different biographical dictionaries. Towards the end of the course we came to talk about the public profiles of scholars and how these profiles affect the enrollment of female students in their disciplines. Starting with a text on the public profile of computer scientists (Hayes), we ended up discussing that of historians. The students described the historian's profile as "bookish," "well-read," and "vocal," because a typical characteristic of historians, according to the students, is their readiness for debate. When I asked about the gender of the typical historian, there was no clear answer. Instead, the group started to talk about Beatrice de Graaf, who is Professor of the History of International Relations and Global Governance at Utrecht University and specializes in the history of terrorism.

De Graaf is a very public historian, in the sense that she is often a guest on TV talk shows explaining the latest news. But the students did not focus on De Graaf's status as public historian or her teaching of history to a general audience, but on the bright red dress she had worn when 
she delivered a TV lecture on terrorism (broadcast on March 12, 2016). This led to a lively discussion about the looks of historians, how clothes or hairdos can influence their authority as historians, and how this might be different for men and women. The big suprise came later though, when the students were packing their bags to leave. One student suddenly remarked that a typical historian cannot be religious, because religion is a bias and an obstacle to the objectivity that historical research requires. For that reason, this student said she never dared mention that she went to church every Sunday. I was glad and proud that she felt safe enough to mention this during our class, but I was also a bit puzzled because Beatrice de Graaf is a very outspoken Christian historian. Still, I do think that this afterthought to our conversation indicates that something had started to happen in the students' heads. Perhaps it was not gender that set them in motion, but the students definitely had come to think about what a scholarly life looks like-in biographical dictionaries, in Wikipedia, and also in their own worlds and minds.

My second observation is that the students never questioned their own biographical work on the female scholar of their choice. None of the students thought that "their woman" was better forgotten; on the contrary, all were motivated to provide "their woman" with a decent Wikipedia biography. This could just mean that students will do whatever is required to get a good grade. But a fairer, and certainly more uplifting, understanding could be that the study and writing of a historical person's life does something to students. Once they learn more about a person, they feel engaged and want to do justice to that person and their life-no matter how other people might think about the historical relevance of that particular life. In this sense, the assignment to write Wikipedia biographies proved a golden route into what was my ultimate goal for the course: to provide more fundamental reflections on neutrality, objectivity, and truth in history in general, and public history in particular.

When we started the course, I thought that Wikipedia's policy of a neutral point of view (NPOV) might hamper my goal. Looking back, I tend to think that the format of a Wikipedia biography was very well-suited to my goal and the type of academic work undergraduate students can deliver in a course period of only eight weeks: relatively short texts that are based on a limited range of secondary sources, accompanied by original photographs and pictures from the University Museum's collection. To the students this assignment was appealing because it was "real work," which was much appreciated by the University Museum and Wikimedia NL. ${ }^{10}$ Moreover, in gathering information for their neutral and factual biographies, the students themselves could experience that a very public historical genre like biography is based on choices, from determining the 
perspective on the person's life to the selection, ordering, and presentation of information on that life. To me, one of the best moments in this fascinating course was thus when one student, after our last edit-a-thon, said that she could no longer read Wikipedia entries as if they contained the truth about their subjects.

\section{ACKNOWLEDGEMENTS}

I would like to thank Hendrik Henrichs, who laid the foundations for the course that I describe here. Many thanks also to Jet Blokhuis, Reina de Raat, and Paul Lambers from the University Museum in Utrecht, and Arne Wossink from Wikimedia NL. Without all of them, this course could never have worked as well as it did. This article is based on papers I presented at the IABA Europe 2017 Conference on "Life Writing, Europe, and New Media," King's College London, 7-9 June 2017, and the Historicidagen conference at Utrecht University, 24-26 August 2017.

\section{WORKS CITED}

Bosch, Mineke. "Women and Science in the Netherlands: A Dutch Case?" Science in Context 15.4 (2002): 483-527.

Clausen, Christopher. "It Is Not Elitist to Place Major Literature at the Center of the English Curriculum." Chronicle of Higher Education 13 January 1988.

Danniau, Fien. "Public History in a Digital Context. Back to the Future or Back to Basics?" BMGN-Low Countries Historical Review 128.4 (2013): 118-144.

Faasse, Patricia. Een beetje opstandigheid. Johanna Westerdijk, de eerste vrouwelijke hoogleraar van Nederland. Amsterdam: Atlas Contact, 2012.

Gates, Jr., Henry Louis. Loose Canons. Notes on the Culture Wars. New York/Oxford: Oxford University Press, 1992.

Graham, Pamela. "An Encyclopedia, Not an Experiment in Democracy': Wikipedia Biographies, Authorship, and the Wikipedia Subject." Biography 38.2 (2015): 222-244.

Gray, Alex. "These Are the World's Most Popular Websites." World Economic Forum 10 April 2017, https://www.weforum.org/agenda/2017/04/most-popular-websites-google-youtube-baidu [Last accessed on: 19 September, 2017].

Halsted, David G. "Accuracy and Quality in Historical Representation: Wikipedia, Textbooks and the Inventure Controversy." Digital Medievalist 9 (2013), par. 2, http://www.digitalmedievalist.org/journal/9/halsted/.

Hayes, Caroline. "Computer Science: The Incredible Shrinking Woman." Ed. Thomas Misa. Gender Codes: Why Women are Leaving Computing. Hoboken, NJ: John Wiley \& Sons, 2010. 25-49.

Jefferson, Thomas. Notes on the State of Virginia. New York: Palgrave Macmillan, 2002.

Kean, Hilda, and Paul Ashton. "Introduction: People and their Pasts and Public History Today." Eds. Paul Ashton and Hilda Kean. Public History and Heritage Today. People and their Pasts. New York: Palgrave Macmillan, 2012. 1-20.

Lih, Andrew. The Wikipedia Revolution: How A Bunch of Nobodies Created The World's Greatest Encyclopedia. New York: Hyperion, 2009. 
Marijke, Huisman. "Weg met het handboek! Een pleidooi voor meer reflexiviteit in academische opleidingen Geschiedenis.” Tijdschrift voor Geschiedenis 130.2 (2017): 261-264.

Nzume, Anousha. Hallo witte mensen. Amsterdam: Amsterdam University Press, 2017.

Reagle, Joseph. "Free as in Sexist? Free Culture and the Gender Gap." First Monday 18.1 (2013): doi:10.5210/fm.v18i1.4291.

Ribbens, Kees, and Maria Grever. "Wikipedia als virtuele graadmeter voor de maatschappelijke rol van geschiedenis." Eds. Leen Dorsman et al. Het nut van geschiedschrijving. Historici in het publieke domein. Opstellen voor Ed Jonker bij zijn afscheid als hoogleraar Grondslagen en Geschiedenis van de Geschiedbeoefening aan de Universiteit Utrecht. Amstelveen: Eon Pers, 2015. 157-165.

Rosenzweig, Roy. "Can History be Open Source? Wikipedia and the Future of the Past." The Journal of American History 93.1 (2006): 117-146.

Rosenzweig, Roy, and David Thelen. The Presence of the Past. Popular Uses of History in American Life. New York: Columbia University Press, 1998.

Samuel, Raphael. Theatres of Memory. Past and Present in Contemporary Culture. London: Verso, 1994.

Saxton, Martha. "Wikipedia and Women's History: A Classroom Experience." Eds. Jack Dougherty and Kristen Nawrotzki. Writing History in the Digital Age. Ann Arbor: University of Michigan Press, 2013. 86-94.

Seligman, Amanda. "Teaching Wikipedia without Apologies.” Eds. Jack Dougherty and Kristen Nawrotzki. Writing History in the Digital Age. Ann Arbor: University of Michigan Press, 2013. 121-130.

Tosh, John. Why History Matters. New York: Palgrave Macmillan, 2008.

Wekker, Gloria. White Innocence. Paradoxes in Colonialism and Race. Durham: Duke University Press, 2016.

Wolff, Robert. "The Historian's Craft, Popular Memory, and Wikipedia.” Eds. Jack Dougherty and Kristen Nawrotzki. Writing History in the Digital Age. Ann Arbor: University of Michigan Press, 2013. 64-74.

\section{ABOUT THE AUTHOR}

Marijke Huisman (b. 1972) is Assistant Professor of Public History in the Department of History and Art History, Utrecht University, the Netherlands. She is co-founder and board member of IABA Europe, the European branch of the International Auto/Biography Association, and has co-edited Life Writing Matters in Europe (Heidelberg: Winter Verlag, 2012). Her research interests focus on auto/biographical representations of the past, and on the relationships between public and academic forms of doing history. Her latest book project (2015) analysed the use of slave narratives in public and academic debates on slavery, its legacy and history in Great Britain, the US, and the Netherlands between 1789 and 2013. E-mail: m.h.huisman@uu.nl.

\section{NOTES}

1 Wikipedia English Article Count, http://wikicount.net/ [Last accessed: 6 November 2017]; Wikipedia Nederlandse Artikelen Telling, http://nl.wikicount.net/ [Last accessed: 6 November 2017]. 
2 Wikipedia: Multiyear ranking of most viewed pages, https://en.wikipedia.org/wiki/ Wikipedia:Multiyear_ranking_of_most_viewed_pages [Last accessed: November 6, 2017].

3 Wikipedia:Top 25 Report, July 30 to August 5, 2017, https://en.wikipedia.org/wiki/ Wikipedia:Top_25_Report/July_30_to_August_5,_2017 [Last accessed: November 6, 2017].

4 In the Netherlands institutions like the Koninklijke Bibliotheek (Royal Library) and Atria, Institute on Gender Equality and Women's History have (had) a Wikipedian in residence. Atria still organizes monthly Wiki Fridays, when staff and volunteers come together to research and write Wikipedia entries in the library of this institute. Evelien Rijsbosch, unpublished paper on Wikipedia and Atria, Conference Historicidagen, session "Wikipedia en Geschiedenis," Utrecht, 25 August, 2017.

5 The minor consisted of four courses: "Public History in the Digital Age" (offered by the Department of History and Art History), "Digital Media \& Memory" (offered by the Department of Media and Cultural Studies), "Schrijven en Blijven" (offered by the Department of Languages, Literature, and Communication), "Debating the Past" (offered by the Department of Languages, Literature, and Communication). As of 2017-2018 the minor is no longer available.

6 Welcome to Wikimedia, https://www.wikimedia.org/ [Last accessed: November 7, 2017].

7 Ina Boudier Bakker (1875-1966) lived a large part of her life in Utrecht. Her novels have not survived the test of time, but her name is still present in many street names in the Netherlands. In Utrecht she is commemorated by the name of a street in which a large student housing complex was built in the 1960s. This complex, "the IBB," is the oldest and still the largest site of student housing in the city of Utrecht. From this perspective, it was not that strange that our guest lecturer expected this name to be familiar to the students.

8 This shows, for instance, from the heated debates on Gloria Wekker's study White Innocence: Paradoxes in Colonialism and Race (Durham: Duke University Press, 2016).

9 See, e.g., Anousha Nzume, Hallo witte mensen (Amsterdam: Amsterdam University Press, 2017), Chapter 6: Wit verleden.

10 Rosanne Vreugdenhil wrote a biography of the physical geographer Jacoba Hol (1886-1964), https://nl.wikipedia.org/wiki/Jacoba_Hol; Pepijn de Groot wrote about prosthetic dentist Jans Schuiringa (1887-1975), https://nl.wikipedia.org/wiki/Jansje_Gretha_Schuiringa; Juliette van Leuven, Maril de Man, and Nikki Kraaijenzank together wrote a large entry on natural scientist and mathematician Caroline Bleeker (1897-1985), https://nl.wikipedia.org/wiki/Caroline_Emilie_Bleeker. Omar Bugter expanded the entry on Johanna Westerdijk with a section on her work promoting female scholars, https://nl.wikipedia.org/wiki/Johanna_Westerdijk;. 